\title{
Revised list of abbreviations for names of enzymes of diagnostic importance
}

\author{
D. N. BARON ${ }^{1}$, D. W. MOSS, P. G. WALKER, AND J. H. WILKINSON
}

From the Royal Free Hospital School of Medicine, London, Royal Postgraduate Medical School, London, Institute of Orthopaedics, Stanmore, and Charing Cross Hospital Medical School, London

\begin{tabular}{|c|c|c|c|}
\hline $\begin{array}{l}\text { EC } \\
\text { Number }\end{array}$ & Recommended Name & $\begin{array}{l}\text { Abbre- } \\
\text { viation }\end{array}$ & \\
\hline 1.1.1.1 & Alcohol dehydrogenase & $\mathrm{AD}$ & \\
\hline 1.1.1.14 & L-Iditol dehydrogenase & ID & (a) \\
\hline 1.1.1.27 & Lactate dehydrogenase & LD & \\
\hline & Hydroxybutyrate dehydrogenase & HBD & \\
\hline 1.1.1.37 & Malate dehydrogenase & MD & \\
\hline 1.1.1.42 & Isocitrate dehydrogenase (NADP ${ }^{+}$ & ICD & \\
\hline 1.1.1.44 & $\begin{array}{l}\text { Phosphogluconate dehydrogenase } \\
\text { (decarboxylating) }\end{array}$ & PGD & \\
\hline 1.1.1.49 & Glucose-6-phosphate dehydrogenas & e GPD & (b) \\
\hline 1.2.1.12 & $\begin{array}{l}\text { Glyceraldehyde-phosphate } \\
\text { dehydrogenase }\end{array}$ & GAD & (c) \\
\hline 1.4.1.3 & $\begin{array}{l}\text { Glutamate dehydrogenase } \\
\left(\mathrm{NAD}(\mathrm{P})^{+}\right)\end{array}$ & GMD & \\
\hline 1.6.4.2 & Glutathione reductase (NAD(P)H) & GTR & \\
\hline 1.11.1.6 & Catalase & CTS & \\
\hline 2.1.3.3 & Ornithine carbamoyltransferase & OCT & \\
\hline 2.2.1.1 & Transketolase & TKT & \\
\hline 2.3.2.2 & $\gamma$-Glutamyltransferase & GGT & (d) \\
\hline 2.6.1.1 & Aspartate transaminase & AST & (e) \\
\hline 2.6.1.2 & Alanine transaminase & ALT & \\
\hline 2.7.1.40 & Pyruvate kinase & PK & \\
\hline 2.7.3.2 & Creatine kinase & CK & \\
\hline 2.7.4.3 & Adenylate kinase & AK & \\
\hline 2.7.5.1 & Phosphoglucomutase & PGM & \\
\hline 2.7.7.12 & $\begin{array}{l}\text { Hexose-1-phosphate } \\
\text { uridylyltransferase }\end{array}$ & HUT & (f) \\
\hline 3.1.1.3 & Triacylglycerol lipase & LPS & (g) \\
\hline 3.1.1.8 & Cholinesterase & CHS & \\
\hline 3.1.3.1 & Alkaline phosphatase & ALP & \\
\hline 3.1.3.2 & Acid phosphatase & ACP & \\
\hline 3.1.3.5 & 5'-Nucleotidase & NTP & \\
\hline 3.2.1.1 & a-Amylase & AMS & \\
\hline 3.2.1.30 & $\beta-N$-Acetylglucosaminidase & AGS & \\
\hline 3.2.1.31 & $\beta$-Glucuronidase & GRS & \\
\hline 3.4.11.2 & Aminopeptidase (microsomal) & LAS & (h) \\
\hline 3.4.11.3 & Cystyl-aminopeptidase & CAS & (i) \\
\hline 3.4.21.4 & Trypsin & TPS & \\
\hline 3.4.23.1 & Pepsin A & PPS & \\
\hline 3.5.3.1 & Arginase & ARS & \\
\hline 3.5.4.3 & Guanine deaminase & GDS & (j) \\
\hline 3.5.4.4 & Adenosine deaminase & ADS & \\
\hline 4.1.2.13 & Fructose-bisphosphate aldolase & ALS & (k) \\
\hline 4.2.1.1 & Carbonate dehydratase & $\mathbf{C A}$ & (l) \\
\hline 5.3.1.1 & Triosephosphate isomerase & TPI & \\
\hline 5.3.1.9 & Glucosephosphate isomerase & GPI & \\
\hline
\end{tabular}

The publication of the new edition of Enzyme Nomenclature (Commission on Biochemical Nomenclature, 1973) contains many changes of enzyme number and recommended name. This has made it necessary to revise the list of abbreviations of clinically important enzymes (Baron, Moss, Walker, and Wilkinson, 1971). Although we have been criticized for our temerity in bringing out this list, it has been sufficiently widely used for revision to be worthwhile. We appreciate that there may be difficulties in using this list with languages other than English, where names of enzymes (particularly in the order of the words) are often different. We have taken the opportunity to make a few other changes and to correct some errors and we are grateful to all those who sent comments. For simplicity, neither numbers nor Greek letters are used in the abbreviations.

\section{(e) Notes}

(a) Usually called sorbitol dehydrogenase

(b) Often abbreviated as G6PD

(c) Formerly called triosephosphate dehydrogenase; TPD

(d) Often called $\gamma$-glutamyltranspeptidase

(e) Transaminase and aminotransferase are per- $\rightarrow$ mitted alternatives by the Commission on Biochemical Nomenclature; AST and ALT serve as N abbreviations for both. Formerly called glutamic oxaloacetic transaminase (GOT) and glutamic pyruvic transaminase (GPT)

(h) (f) Often called (eg, relating to galactosaemia)

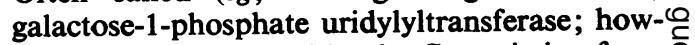
ever, this name is used by the Commission for a different enzyme, EC 2.7.7.10

(g) Usually called lipase

(h) Often called leucine aminopeptidase or arylamidase

${ }^{1}$ Correspondence to Professor D. N. Baron, Department of Chemical $\bar{C}$ Pathology, The Royal Free Hospital, Pond Street, London NW3 2QG

Received for publication 6 January 1975. 
(i) Formerly called oxytocinase

(j) Formerly called guanase

(k) Usually called aldolase

(l) Formerly called carbonic anhydrase
References

Baron, D. N., Moss, D. W., Walker, P. G., and Wilkinson, J. H. (1971). Abbreviations for names of enzymes of diagnostic importance. J. clin. Path., 24, 656-657.

Commission on Biochemical Nomenclature (1973). Enzyme Nomenclature. Elsevier, Amsterdam.

\section{Reports and Bulletins prepared by the Association of Clinical Biochemists}

The following reports and bulletins are published by the Association of Clinical Biochemists. They may be obtained from The Publishing Department, British Medical Journal (ACB Technical Bulletins), B.M.A. House, Tavistock Square, London WC1H 9JR. Overseas readers should remit by British Postal or Money Order.

SCIENTIFIC REPORTS (price $£ 1.00 / \$ 2.00$ each)

3 Automatic Dispensing Pipettes: an assessment of 35 commercial instruments September 1967 P. M. G. BROUGHTON, A. H. GOWENLOCK, G. M. WIDDOWSON, and K. A. AHLQUIST

4 An Evaluation of five Commercial Flame Photometers suitable for the Simultaneous Determination of Sodium and Potassium March 1970 P. M. G. BROUGHTON and J. B. DAWSON

SCIENTIFIC REVIEWS (price $£ 1 \cdot 00 / \$ 2.00$ each)

1 The Assessment of Thyroid Function March 1971 F. V. FLYNN and J. R. HOBBS

2 Renal Function Tests Suitable for Clinical Practice January 1972 F. L. MITCHELL, N. VEALL, and R. W. E. WATTS

3 Biochemical Tests for the Assessment of Fetoplacental Function May 1975 C. E. WILDE and R. E. OAKEY

TECHNICAL BULLETINS (price $₫ 1 \cdot 00 / \$ 2.00$ each)

9 Determination of Urea by AutoAnalyzer November 1966 RUTH M. HASLAM

11 Determination of Serum Albumin by AutoAnalyzer using Bromocresol Green October 1967 B. E. NORTHAM and G. M. WIDDOWSON

13 An Assessment of the Technicon Type II Sampler Unit March 1968 B. C. GRAY and G. K. MOGOWAN

14 Atomic Absorption Spectroscopy: an outline of its principles and a guide to the selection of instruments May 1968 J. B. DAWSON and P. M. G. BROUGHTON

15 A Guide to Automatic Pipettes (2nd edition) June 1968 P. M. G. BROUGHTON

16 A Guide to Automation in Clinical Chemistry May 1969 P. M. G. BROUGHTON

17 Flame Photometers: a comparative list of 17 instruments readily available in Britain August $1969 \mathrm{P}$. WIIDING

19 Spectrophotometers: a comparative list of low-priced instruments readily available in Britain May 1970 C. E. WILDE and P. SEWELL
20 Quantities and Units in Clinical Biochemistry June 1970 P. M. G. BROUGHTON

21 Filter Fluorimeters: A comparative list of 18 instruments September 1970 H. BRAUNSBERG and s. S. BROWN

22 Bilirubin Standards and the Determination of Bilirubin by Manual and Technicon AutoAnalyzer Methods January 1971 BARBARA BILLING, RUTH HASLAM, and N. WALD

23 Interchangeable Cells for Spectrophotometers and Fluorimeters September 1971 S. S. BROWN and A. H. GOWENLOCK

24 Simple Tests to Detect Poisons March 1972 B. w. MEADE et al.

25 Blood Gas Analysers May 1972 K. DrxoN

26 Kits for Enzyme Activity Determination September 1972 S. B. ROSALKI and D. TARLOW

27 Assessment of Pumps Suitable for Incorporation into Existing Continuous Flow Analytical Systems November 1972 A. FLECK et al.

28 Routine Clinical Measurements of Transferrin in Human Serum September 1973 K. DxXON

29 Control Materials for Clinical Biochemistry (5th edition) September 1973 J. F. STEVENS

30 Notes on the Quality of Performance of Serum Cholesterol Assays September 1973 s. S. BROWN

31 Determination of Uric Acid in Blood and in Urine July 1974 R. W. E. WATTS

32 A Survey of Amino Acid Analysers Readily Available in the United Kingdom September 1974 J. E. CARLYLE and P. PURKISS

33 Definitions of some Words and Terms used in Automated Analysis November 1974 A. FLECK, R. ROBINSON, S. S. BROWN, and J. R. HOBBS

34 Measurement of Albumin in the Sera of Patients January 1975 LINDA SLATER, P. M. CARTER, and J. R. HOBBS

35 Investigation of the Validity of Temperature Correction Factors for Serum Aspartate and Alanine Transaminases March 1975 s. B. ROSALKI et al. 